\title{
Kewenangan Notaris Dalam Pembuatan Akta Otentik Berkaitan Dengan Kontrak Kerjasama
}

\author{
Maslikan", Sukarmi*
}

\author{
* Mahasiswa Program Magister (S2) Kenotariatan Fakultas Hukum UNISSULA, Semarang \\ ** Dosen Fakultas Hukum UNISSULA
}

\begin{abstract}
Abstrak
Dalam pasal 1 ayat (1) UU No 30 Tahun 2004 tentang Jabatan Notaris, Notaris adalah pejabat umum yang berwenang untuk membuat akta otentik dan kewenangan lainnya sebagaimana dimaksud dalam undang-undang ini. Salah satu kewenangan notaris adalah membuat akta otentik, dimana hal tersebut sesuai dengan ketentuan dalam pasal 15 UU No 30 Tahun 2004 tentang Jabatan Notaris.

Hal ini penulis mencoba menelaah kewenangan notaris dalam pembuatan akta otentik berkaitan dengan kontrak kerjasama.Peneitian ini menggunakan metode penelitian hukum normative, dimana pendekatan penelitian yang digunakan adalah pendekatan perundang-undangan dan pendekatan konseptual.

Akta-akta yang dibuat oleh Notaris misalnya pedirian Perseroan Terbatas (PT), perubahan dan risalah umum pemegang saham, pendirian yayasan, pendirian bahan usaha-badan usaha lainnya, kuasa untuk menjual, perjanjian sewa menyewa, perjanjian jual beli, keterangan hak waris, wasiat, pendirian CV termasuk perubahannya, pengakuan utang, perjanjian kredit dan dan pemberian hak tanggungan, perjanjian kerjasama, kontrak kerja, segala bentuk perjanjian yang tidak dikecualikan kepada pejabat lain, oleh sebab itu akta yang berkaitan dengan kontrak kerjasama mutlak merupakan wewenang oleh sorang Notaris untuk membuat akta otentik tersebut

Kata Kunci : kewenangan notaris, akta otentik, kontrak kerjasama
\end{abstract}

\begin{abstract}
In article 1 paragraph (1) of Law No 30 Year 2004 concerning Notary Public, Notary is a public official authorized to make authentic deed and other authority as referred to in this law. One of the authority of a notary is to make an authentic deed, which is in accordance with the provisions of Article 15 of Law No 30 Year 2004 regarding Notary Position.

This author tries to examine the authority of notary in making authentic deed related to cooperation contract. This research uses normative law research method, where the research approach used is the approach of legislation and conceptual approach.

Notarial deeds made by a Notary, such as the establishment of a Limited Liability Company (PT), general shareholder changes and minutes, establishment of foundations, establishment of materials of other business entities, authorization to sell, lease agreements, sale and purchase agreements, inheritance rights, , the establishment of the CV including amendments, recognition of debts, credit agreements and the granting of mortgages, cooperation agreements, contracts of employment, all forms of agreements not excluded to other officials, therefore deeds relating to the contract of cooperation are absolutely authorized by a Notary to make the authentic deed

Keywords: notary authority, authentic deed, cooperation contract
\end{abstract}

\section{PENDAHULUAN}

Dapat dipahami bahwa awal dari adanya kontrak kerjasama adalah kesepakatan.Tanpa adanya kesepakatan maka tidak ada perjanjian.Hal ini sesuai dengan ketentuan pasal 1313 BW.Artinya, adanya kata sepakat merupakan kunci dari lahir dan sahnya suatu perjanjian (kerjasama).Namun untuk melihat apakah suatu kontrak kerjasama lahir dari suatu kata sepakat yang sah tidaksemudah membalik telapak tangan.

Lain halnya untuk melihat dipenuhi atau tidaknya syarat syarat sahnya suatu kontrak kerjasama yang lainnya yakni kecakapan, obyek yang tertentu dan suatu sebab yang diperbolehkan syarat-syarat ini dengan mudah dapat diketahui, karena parameternya sudah sangat jelas dan terlihat baik dari subyek maupun obyek kontrak kerjasamanya.

Dalam beberapa hal, ada yang membuat suatu kontrak kerjasama harus memiliki bukti kuat dimata hukum yang berlaku.Oleh karean hal tersebut pihak yang melakukan kontrak kerjasama membuat memilih membuat akta otentik.

Notaris adalah orang yang mendapat wewenang dari pemerintah untuk menyaksikan dan mengesahkan berbagai surat menyurat yang 
berkenaan dengan hukum (misalnya surat perjanjian (kontrak kerjasama), wasiat, dsb). ${ }^{1}$ Dalam pasal 1868 KUH Perdata mensyaratkan supaya suatu akta mempunyai kekuatan bukti otentik maka harus dibuat oleh Pejabat Umum yang berwenang.Jadi tidak setiap orang dapat atau boleh membuat akta otentik, tetapi hanya pejabat umum yang diberi wewenang oleh undang-undang untuk membuat akta otentik.

Kewenangan notaris diatur dalam pasal 15 ayat (2) dan ayat (3) UU No 30 Tahun 2004, yang berbunyi : (2) Notaris berwenang pula : a. Mengesahkan tanda tangan dan menetapkan kepastian tanggal surat dibawah tangan dengan mendaftar dalam buku khusus, b. Membukukan surat-surat dibawah tangan dengan mendaftar dalam buku khusus, c. Membuat kopi dari asli surat-surat di bawah tangan berupa salinan yang memuat uraian sebagaimana ditulis dan digambarkan dalam surat yang bersangkutan, d. Melakukan pengesahan kecocockan fotokopi dengan surat aslinya, e. Membuat akta yang berkaitan dengan pertanahan $\mathrm{g}$. Membuat akta risalah lelang (3) Selain kewenangan sebagimana dimaksud pada ayat (1) dan ayat (2), Notaris mempunyai kewenangan lain yang diatur dalam peraturan perundang-undangan.

Salah satu kewajiban notaris yaitu membaca akta, dimana hal ini tercantum dalam pasal 16 ayat (1) huruf I, yang berbunyi : Membacakan akta dihadapan penghadap dengan dihadiri oleh paling sedikit 2 (dua) orang saksi dan ditandatangani pada saat itu juga oleh penghadap, saksi dan Notaris.

Ketentuan pasal 16 ayat (1) huruf I ini mendapat pengaturan lebih lanjut dalam pasal 16 ayat (7) dana ayat (8), bahwa (7). Pembacaan akta sebagaimana dimaksud pada ayat (1) huruf I tidak wajib dilakukan, jika penghadap menghendaki agar akta tidaak dibacakan karena penghadap telah membaca sendiri, mengetahui, dan memahami isinya, dengan ketentuan bahwa hal tersebut dinyatakan dalam penutup akta serta pada setiap halaman Minuta Akta diparaf oleh penghadap, saksi,dan Notaris. (8). Jika salah satu syarat sebagaimana dimaksud pada ayat (1) huruf I dan ayat (7) tidak dipenuhi, akta yangbersangkutan hanya mempunyai kekuatan pembuktian sebagi akta di bawah tangan.

Sedangkan ketentuan pembaca akta juga diatur dalam pasal 44 ayat (1) UU No 30 Tahun 2004 bahwa, Segera setelah akta dibacakan, akta tersebut ditandatangani oleh setiap penghadap, saksi, dan Notaris, kecuali apabila adapenghadap yang tidak

\footnotetext{
1 Umi Chulsum dan Windy Novia.Kamus Besar
} BahasaIndonesia. Surabaya : Kashiko. 2004. Halaman 484 dapat membubuhkan tanda tangan dengan menyebutkan alasannya. Dari ketentuan-ketentuan UU No 30 Tahun 2004 di atas, dapat diketahui bahwa dalam kaitannya dengan akta kontrak kerjasama yang dibuat secara notarial, maka kewenangan notaris dalm menyusun, membacakan dan menandatangi akta.

Sebagai seorang notaris, yang merupakan pejabat umum, tentu saja notaris harus dalam keadaan netral diantara kedua belah pihak atau dengan kata lain tidak memihak salah satu pihak dlam pembuatan suatu akta kontrak kerjasama. Notaris seharusnya benar-benar memperhatikan dokumen-dokument dan kenyataan yang terjadi dilapangan yang berhubungan dengan akta yang dibuatnyasupaya tidak menimbulkan kerugian bagipara pihak yang membuat akta tersebut.Pihak yang menderita kerugian karena akta tersebut yang dibuat oleh notaris tersebut menjadi hanya memiliki kekuatan sebagai akta bawah tangan, maka pihak tersebut dapat menuntut penggantian biaya, ganti rugi dan bunga kepada notaris. Notaris juga dapat dikenakan sanksi lain berupa teguran lisan, teguran tertulis, pemberhentian sementara, pemberhentian dengan hormat atau pemberhentian dengan tidak hormat, oleh Majelis Pengawas sebagimana diatur oleh UU No 30 Tahun 2004 tentang Jabatan Notaris. 2

Berdasarkan uraian tersebut di atas, tentang kewenangan notaris dalam pembuatan akta otentik berkaitan dengan kontrak kerjasama, maka perlu dilakukan kajian tentang kewenangan notaris dalam membuat akta otentik tersebut.

\section{Metode Penelitian}

Pada penelitian ini penulis menggunakan penelitian hukum normatif. Penelitian hukum normatif menurut Mukti Fajar ND dan Yulianto Ahmad adalah penelitian hukum yang meletakkan hukum sebagai sistem norma. Sistem norma yang dimaksud adalah mengenai asas-asas, norma, kaidah dari peraturan perundang-undangan, putusan pengadilan, perjanjian serta doktrin (ajaran). ${ }^{3}$ Pendekatan penelitian yang digunakan dalam penelitian ini adalah pendekatan perundangundangan (statute approach) dan pendekatan konseptual (conceptual approach).Menggunakan pendekatan perundang-undangan penelitian normatif ini karena yang akan di analisa adalah aturan hukum yang menjadi fokus sekaligus tema sentral suatu

\footnotetext{
${ }^{2}$ Pasal 84 dan pasal 85 UU No 30 Tahun 2004 tentang Jabatan Notaris

${ }^{3}$ Mukti Fajar ND dan Yulianto Achmad, Dualisme Penelitian Hukum Normatif dan Hukum Empiris, (Yogyakarta: Pustaka Pelajar, 2010), hlm. 34.
} 
penelitian. Sedangkan pendekatan konseptual beranjak dari pendapat para sarjana dan doktrindoktrin yang berkembang dalam ilmu hukum. Dengan demikian akan ditemukan ide-ide yang melahirkan pengertian-pengertian hukum, konsepkonsep hukum, dan asas-asas hukum yang relevan dengan isu yang dihadapi.

Sumber bahan penelitian normative ini dibagi menjadi seber penelian yang berupa bahan hukum primer, bahan hukum sekunder, dan bahan hukum tersier. Bahan hukum pimer adalah bahan hukum yang terdiri atas peraturan perundangan, risalah resmi, putusan pengadilan, dan dokumen resmi Negara. Bahan hukum primer yang akan digunakan dalam penelitian ini antara lain sebagai berikut : Kitab Undang-Undang Hukum Perdata, Undang-undang Pokok Agraria Nomor : 5 Tahun 1960, Undang-Undang Republik Indonesia Nomor : 30 Tahun 2004 tentang Jabatan Notaris. Jo Undangundang Nomor : 2 Tahun 2004, Peraturan Pemerintah, Laporan Bahan Legislasi DPR RI, Pendapat Fraksi DPR RI serta Risalah Rapat pembahasan RUU Jabatan Notaris.

Bahan hukum sekunder dalam penelitian ini terdiri dari buku-buku teks, jurnal-jurnal hukum, pendapat para sarjana, dan hasil penelitian hukum, yang dapat memberikan penjelasan mengenai bahan-bahan hukum primer. Sedangkan bahan hukum tersier itu sendiri merupakan bahan hukum yang memberikan petunjuk maupun penjelasan terhadap bahan hukum primer maupun bahan hukum sekunder yakni berupa kamus. Bahan ini menjadi penting karena mendukung dalam proses analisis hukumnya. Bahan hukum tersier yang digunakan juga hanya bahan hukum yang berhubungan secara langsung dengan materi penelitian ini.

Bahan hukum primer diperoleh dengan cara mencari dan mengumpulkan Peraturan Perundangundangan yang terkait kewenangan notaris dalam membuat akta yang berkaitan dengan pertanahan. Bahan hukum sekunder diperoleh dengan cara mengumpulkan literatur-literatur baik yang diperoleh melalui buku-buku teks, jurnal-jurnal, dan mungkin juga dari hasil penelitian terdahulu yang berkaitan dengan isu hukum dalam penelitian ini. Sedangkan bahan tersier dapat diperoleh dengan mengumpulkan artikel dari media cetak dan elektronik (internet) atau juga diperoleh melalui kamus hukum serta ensiklopedia hukum yang memiliki keterkaitan dengan isu hukum dalam penelitian ini.

Setelah bahan hukum primer, bahan hukum sekunder, dan bahan hukum tersier dikumpulkan, penulis akan uraikan, deskripsikan, dan analisis sehingga dapat menjawab permasalahan mengenai permasalahan kewenangan notaris dalam membuat akta yang berkaitan dengan pertanahan. Analisis bahan hukum dalam penelitian normatif menggunakan anlisis kualitatif.Anilisis kualitatif memberikan gambaran-gambaran (deskripsi) dengan kata-kata atas temuan-temuan sehingga lebih mengutamakan mutu/kualitas dari bahan hukum.

\section{HASIL PENELITIAN DAN PEMBAHASAN}

\section{Kewenangan Notaris dalam Pembuatan akta otentik berkaitan dengan kontrak kerjasama}

Berdasarkan pasal 1 ayat (1) UU No 30 Tahun 2004 tentang Jabatan Notaris, Notaris adalah pejabat umum yang berwenang untuk membuat akta otentik dan kewenangan lainnya sebagaimana dimaksud dalam undang-undang ini. Sebelum notaris membuat akta, tentu saja para pihak harus menghadap notaris untuk menjelaskan maksud dalam pembuatan akta apa yang ingin dibuat oleh para pihak.

Berasarkan hasil penelitian penuis, pada saat awal para pihak menghadap notaris, notaris memiliki 2 fungsi yaitu pertama, menyerap keinginan para pihak dengan tepat. Untuk menyerap keinginan para pihak dengan tepaat, maka notaris harus banyak bertanya kepada para pihak supaya notaris mengetahui apa yang diinginkan oleh para pihak. Umumnya di Indonesia para pihak yang menghadap notaris adalah orang yang buta hukum, sehingga mereka tidak tahu akta apa yang harus dibuat dan kadang kala keinginan para pihak belum tentu tepat secara hukum. Hal ini berarti dari kacamata hukum apa yang diinginkan oleh para pihak tersebut tidak tepat/tidak bisa dipenuhi.

Sedangkan fungsi kedua dari notaris adalah menuangkan terlebh dahulu keinginan para pihak dalam bentuk tulisan, atatu dikenal dengan istilah draf akta. Jadi draf akta ini nantinya akan dibuat akta di hadapan notaris yang berisi kehendak kedua belah pihak dan dibuat berdasarkan ketentuan hukum yang berlaku. Kemudian notaris menjelaskan maksud dari draf tersebut kepada para ihak.Jika draf tersebut telah sesuai dengan keinginan para pihak, baru notaris membuat minuta akta.Setelah dibuat minuta akta, pada hari yang telah ditentukan, kedua pihak dating menghadap notaris dan notaris kemudian membacakan serta menjelaskan isi akta tersebut kepada para pihak. Setelah akta itu dibacakan, maka kedua pihak, saksi dan notaris

\section{Ruang Lingkup Kontrak Kerjasama}

Istilah kontrak berasal dari bahasa inggris yaitu contracts, sedangkan dalam bahasa Belanda 
disebut dengan overeenkomst (perjanjian), ${ }^{4}$ Banyak definisi kontrak yang telah diberikan. Salah satu definisi kontrak yang diberikan oleh salah satu kamus adalah bahwa kontrak adalah suatu kesepakatan yang diperjanjikan di antara dua atau lebih piak yang dapat menimbulkan, memodifikasi, atau menghilangkan hubungan hukum. ${ }^{5}$

Menurut Soedjono, "Kontrak adalah suatu janji atau seperangkat janji-janji dan akibat pengingkaran atau pelanggaran atasnya hukum memberikan pemulihan atau menetapkan kewajiban bagi yang ingkar janji disertai sanksi untuk pelaksanaanya." Menurut beliau, setiap kontrak setidak-tidaknya melibatkan 2 pihak yaitu pihak yang menawarkan (pihak yang mengajukan penawaran untuk membuat suatu kontrak) dan pihak yang ditawarkan (pihak terhadap siapa kontrak tadi ditawarkan). ${ }^{6}$

Menurut pasal $1313 \mathrm{KUH}$ Perdata, "Perjanjian adalah suatu perbuatan dimana satu orang atau lebih mengikatkan dirinya terhadap satu orang lain atau lebih." Menurut hemat penulis, kontrak adalah perjanjian atau kerjasama antara 2 pihak atau lebih dengan berdasarkan kesepakatan dan adanya hubungan hukum, subyek hukum dan berdasarkan hukum. tujuan: ${ }^{7}$

Menurut P.S Atiyah, kontrak memiliki 3

1. Janji yang telah diberikan harus dilaksanakan dan memberikan perlindungan terhadap suatu harapan yangpantas

2. Agar tidak terjadi suatu penambahan kekayaan yang tidak halal

3. Agar terhindarnya suatu kerugian

Asas-asas kontrak dalam KUH Perdata ada beberapa yaitu: ${ }^{8}$

1. Setiap orang dianggap mengetahui hukum ${ }^{9}$ Dengan asas ini, setiap orang iasumsikan

\footnotetext{
${ }^{4}$ Salim H.S. Hukum Kontrak-Teori dan Teknik Penyusunan Kontrak, Jakarta : Sinar Grafika. 2003. Halaman 25

${ }^{5}$ Munir Fuady. Hukum Kontrak (Dari Sudut Pandang Hukum Bisnis),Bandung : Citra Aditya Bakti. 2001. Halaman 4

${ }^{6}$ Soedjono Dirdjosisworo. Kontrak Bisnis (Menurut Sistem Civil Law, Common Lw dan Praktek dagang Internasional), Bandung : Mandar Maju. 2003. Halaman 29

${ }^{7}$ Atiyah.An Introduction to Low of Contract. New York : Oxford University Press Inc. 1995. Halaman 35 yang dikutip dalam Johannes Ibrahim.Mengupas Tuntas Kredit Komersial dan Konsumtif (Perspektif Hukum dan Ekonomi),Bndung : Mandar Maju. 2004. Halaman 24

${ }^{8}$ Munir Fuady. Op.cit. halaman 29-32

9 Djuhsendah Hasan. Pengkajian Masalah Hukum Kebebasan Berkontrak dan Perlindungan yang Seimbang bagi Para Pihak dalam Perjanjian Kredit Bank di Indonesia, Jakarta : Badan Pembinaan Hukum Nasional Departeen Kehakiman dan Ham RI. 2004. Halaman 23
}

mengetahui dan mengenal huku, dengan demikian setiap orang dan pelaku bisnis di Indonesia dianggap mengetahui setiap semua peraturan hukum yang berkaitan dengan kegiatan bisnis di Indonesia khususnyaperaturan-eraturan hukum yang berkaitan dengan bidang hukum kontrak.

2. Asas Kebebasan Berkontrak Kerjasama, Artinya para pihak bebas membuat kontrak kerjasama dan mengatur sendiri isi kontrak kerjasama tersebut, sepanjang memenuhi ketentuan. Ketentuan ini berarti memenuhi syarat sebagai kontrak kerjasama antara satu pihak dengan pihak lainnya, tidak dilarang oleh Undangundang ,

3. sesuai dengan kebiasaan yang berlaku, dan sepanjang kontrak kerjasama dilaksanakan dengan itikad baik.

4. Asas kebebasab berkontrak adalah suatu asas yang memberikan kebebasan pada para pihak untuk membuat atau tidak membuat perjanjian, mengadakan perjanjian dengan siapapun, menentukan isi perjanjian dan pelaksanaan serta persyaratannya, menentukan bentuk perjanjian yaitu tertulias atau lisan. ${ }^{10}$

5. Asas Pcta Sunt Servanda, sering disebut juga asas kepastian hukum. Artinya suatu kontrak yang dibuat secara sah mempunyai ikatan hukum yangpenuh, dimana hakim atau pihak ketiga harus menghormati substansi kontrak yang dibuat oleh pihak, sebagaimana layaknya sebuah undang-undang.

6. Asas Konsensual daru suatu kontrak kerjasama Artinya bahwa suatu kontrak kerjasama sudah sah dan mengikat ketika tercapai kata sepakat, tentunya selama syarat-syarat sah kontrak kerjasama lainnya sudah dipenuhi.Jadi dengan adanya kata sepakat, kontrak kerjasama tersebut sudah mengikat dan sudah mempunyai akibat hukum, sehingga sejak saat itu telah timbul hak dan kewajiban diantara para pihak.

7. Asas Itikad Baik, Suatu perjanjian harus dilaksanakan dengan itikad baik. ${ }^{11}$

8. Asas Kesamaan dalam Hukum, Para pihak pada dasarnya diberikan kedudukan dan mempunyai kedudukan yang sama, diberikan hak dan mempunyai hak yang sama dan diberikan kewajiban serta akan mempunyai kewajiban sebagaimana sesuai dengan perjanjian.

\footnotetext{
${ }^{10}$ Salim H.S. Perkembangan Hukum Kontrak Innominaat di Indonesia, Jakarta : Sinar Grafika. 2004. Halaman 9

${ }^{11}$ Djuhaendah Hasan. Op.cit. halamn 24
} 
Agar suatu kontrak kerjasama sah sehingga mengikat kedua belah pihak maka harus memenuhu syarat-syarat: ${ }^{12}$

1. Syarat sah yang umum, Berdasarkan pasal 1320 KUH Perdata: 1) Kesepakatan kehendak, 2) Kecakapan berbuat dari para pihak (kecakapan atau kemampuan untuk melakukan perbuatan hukum), 3) Suatu hal tertentu (perihal yang merupakan objek dari suatu kontrak), 4) Suatu sebab yang halal/illegal (sebab mengapa kontrak tersebut dibuat)

2. Syarat sah yang khusus. Terdiri dari syarat tertulis untuk kontrak-kontrak kerjasama tertentu, syarat akta notaris untuk kontrakkontrakkerjasama tertentu, syarat akta pejabat tertentu (yang bukan notaris) untuk kontrakkontrak tertentu, syarat ijin dari yang berwenang.

\section{Profesi Notaris}

Notaris adalah orang yang memdapat wewenang dari pemerintah untuk menyaksikan dan mengesahkan berbagai surat menyurat yang berkenaan dengan hukum (misalnya surat perjanjian, wasiat, akta, dsb). ${ }^{13}$

Dalam pasal $1868 \mathrm{KUH}$ Perdata mensyaratkan supaya suatu akta mempunyai kekuatan bukti otentik maka harus dibuat oleh Pejabat Umum yang berwenang.Jadi tidak setiap orang dapat atau boleh membuat akta otentik, tetaoi hanya pejabat umum yang diberi wewenang oleh undang-undang untuk membuat akta otentik.

Sehubungan dengan kewenangan notaris tersebut, maka ada 4 hal kewenangan yaitu :

1. Berwenang sepanjang yang menyangkut akta yang dibuatnya itu.

2. Berwenang sepanjang mengenai orang untuk kepentingan siapa akta itu dibuatnya.

3. Berwenang sepanjang mengenai temoat dimana akta itu dibuat. Jika tidak maka akta yang dibuatnya tidak sah.

4. Berwenang sepanjang mengenai waktu pembuatan akta itu.

Kewenangan Notaris dalam pasal 1 ayat (1) UU No 30 Tahun 2004 diperjelas dalam ketentuan pasal 15 ayat (1) UU No 30 Tahun 2004 yang berbunyi: Notaris berwenang membuat akta otentik mengenai semua perbuatan perjanjian, dan ketetapan yang diharuskan oleh peraturan perundang-undangan dan/atau yang dikehendaki oleh yang berkepentingan untuk dinyatakan dalam akta otentik, menjamin kepastian tanggal pembuatan

\footnotetext{
${ }^{12}$ Ibid. halaman 25

${ }^{13}$ Umi Chulsum dan Windy Novia. Kamus Besar Bahasa Indonesia,Surabaya : Kashiko. 2006. Halaman 484
}

akta, menyimpan akta, memberikan grosse, salinan dan kutipan akta, semuanya itu sepanjang pembuatan akta-akta itu tidak juga ditugaskan atau dikecualikan kepada pejabat lain atau orang lain yang ditetapkan oleh undang-undang.

Selain itu, ada kewenangan notaris lainnya yang diatur dalam pasal 15 ayat (2) UU No 30 Tahun 2004 yaitu: Notaris berwenang pula:

a. Mengesahkan tanda tangan dan menetapkan kepastian tanggal surat di bawag tangan dengan mendaftar dalam buku khusus

b. Membukukan surat-surat di bawah tangan dengan mendaftar dalam buku khusus

c. Membuat kopi dari asli surat-surat dibawah tangan berupa salinan yang memuat uraian sebagaimana ditulis dan digambarkan dalam surat yang bersangkutan

d. Melakukan pengesahan kecocokan fotokopi dengan surat aslinya

e. Memberikan penyuluhan hukum sehubungan dengan pembuatan akta

f. Membuat akta yang berkaitan dengan pertanahan

g. Membuat akta risalah lelang

Akta-akta yag boleh dibuat oleh Notaris misalnya pedirian Perseroan Terbatas (PT), perubahan dan risalah umum pemegang saham, pendirian yayasan, pendirian bahan usaha-badan usaha lainnya, kuasa untuk menjual, perjanjian sewa menyewa, perjanjian jual beli, keterangan hak waris, wasiat, pendirian CV termasuk perubahannya, pengakuan utang, perjanjian kredit dan dan pemberian hak tanggungan, perjanjian kerjasama, kontrak kerja, segala bentuk perjanjian yang tidak dikecualikan kepada pejabat lain. ${ }^{14}$

Dalam melaksanakan profesinya sebagai notaris, sesuai kewenangan dan kewajibannya, jika notaris melakukan pelanggaran tentu saja ada sanksi yang harus diterima.Ketentuan tentang sanksi ini diatur dalam pasal 84 dan UU No 30 Tahun 2004, bahwa

Tindakan pelanggaran yang dilakukan oleh Notaris terhadap ketentuan sebagaimana dimaksud dalam pasal 16 ayat (1) hurf I, pasal 16 ayat (1) pasal 52 yang mengakibatkan suatu akta hanya mempunyai kekuatan pembuktian sebagai akta dibawah tangan atau suatu akta menjadi batal demi hukum dapat menjadi alas an bagi pihak yang menderita kerugian untuk menuntut penggantian biaya, ganti rugi dan buga kepada Notaris.

Pelanggaran ketentuan sebagaimana dimaksud dalam pasal 7, pasal 16 ayat (1) huruf a,

\footnotetext{
14 http://osinaga.wordpress.com/2007/05/03/beda-notarisdan-ppat/ Notaris dan PPAT-Diakses tanggal 06 Januari 2018
} 
pasal 16 ayat (1) huruf $b$, pasal 16 ayat (1) huruf $c$, pasal 16 ayat (1) huruf d, pasal 16 ayat (1) huruf pasal 16 ayat (1) huruf e, pasal 16 ayat (1) huruf $f$, pasal 16 ayat (1) huruf $g$, pasal 16 ayat (1) huruf $h$, pasal 16 ayat (1) huruf $I$, pasal 16 ayat (1) huruf $j$, pasal 16 ayat (1) huruf $k$, pasal 17 , pasal 27 , pasal, 32, pasal 37, pasal 54, pasal 58, pasal 59, dan/atau pasal 63, dapat dikenakan sanksi berupa:
1. Teguran lisan
2. Teguran tertulis
3. Pemberhentian sementara
4. Pemberhentian dengan hormat, atau
5. Pemberhentian dengan tidak hormat

\section{Kesimpulan}

Kesimpulan dari hasil penelitian dan pembahasan tentang kewenangan notaris dalam pembuatan akta otentik berkaitan dengan kontrak kerjasama tersebut diatas adalah sebagai berikut: Akta-akta yang dibuat oleh Notaris misalnya pedirian Perseroan Terbatas (PT), perubahan dan risalah umum pemegang saham, pendirian yayasan, pendirian bahan usaha-badan usaha lainnya, kuasa untuk menjual, perjanjian sewa menyewa, perjanjian jual beli, keterangan hak waris, wasiat, pendirian CV termasuk perubahannya, pengakuan utang, perjanjian kredit dan dan pemberian hak tanggungan, perjanjian kerjasama, kontrak kerja, segala bentuk perjanjian yang tidak dikecualikan kepada pejabat lain, oleh sebab itu akta yang berkaitan dengan kontrak kerjasama mutlak merupakan wewenang oleh sorang Notaris untuk membuat akta otentik tersebut.

\section{Daftar Pustaka}

Atiyah.An Introduction to Low of Contract. New York : Oxford University Press Inc. 1995. Halaman 35 yang dikutip dalam Johannes
Ibrahim.Mengupas Tuntas Kredit Komersial dan Konsumtif (Perspektif Hukum dan Ekonomi),Bndung : Mandar Maju. 2004

Djuhsendah Hasan. Pengkajian Masalah Hukum Kebebasan Berkontrak dan Perlindungan yang Seimbang bagi Para Pihak dalam Perjanjian Kredit Bank di Indonesia, Jakarta : Badan Pembinaan Hukum Nasional Departeen Kehakiman dan Ham RI. 2004

Mukti Fajar ND dan Yulianto Achmad, Dualisme Penelitian Hukum Normatif dan Hukum Empiris, (Yogyakarta: Pustaka Pelajar, 2010)

Munir Fuady. Hukum Kontrak (Dari Sudut Pandang Hukum Bisnis),Bandung : Citra Aditya Bakti. 2001

Salim H.S. Perkembangan Hukum Kontrak Innominaat di Indonesia,Jakarta : Sinar Grafika. 2004

Salim H.S. Hukum Kontrak-Teori dan Teknik Penyusunan Kontrak, Jakarta : Sinar Grafika. 2003

Subekti Hukum Perjanjian, Jakarta : Intermasa. 1990

Soedjono Dirdjosisworo. Kontrak Bisnis (Menurut Sistem Civil Law, Common Lw dan Praktek dagang Internasional), Bandung : Mandar Maju. 2003

Umi Chulsum dan Windy Novia.Kamus Besar Bahasa Indonesia. Surabaya : Kashiko. 2004. Halaman 484Pasal 84 dan pasal 85 UU No 30 Tahun 2004 tentang Jabatan Notaris

http://osinaga.wordpress.com/2007/05/03/bedanotaris-dan-ppat/ Notaris dan PPAT-Diakses tanggal $\quad 06 \quad$ Januari 2018 